\title{
Determining and assessing the risks of commercial and recreational complex building projects in developing countries: a survey of experts in Iran
}

\author{
Mojtaba Khosravi \\ Department of Civil Engineering, Najafabad Branch, Islamic Azad University, Isfahan 81595-39998, \\ Iran; Email: m.khosravi@khuisf.ac.ir \\ Hadi Sarvari (Corresponding author) \\ Department of Civil Engineering, Isfahan (Khorasgan) Branch, Islamic Azad University, Isfahan 81595- \\ 39998, Iran; Email: h.sarvari@khuisf.ac.ir

\section{Daniel W.M. Chan} \\ Department of Building and Real Estate, The Hong Kong Polytechnic University, Hung Hom, Kowloon, \\ Hong Kong, China, Email: daniel.w.m.chan@polyu.edu.hk

\section{Matteo Cristofaro} \\ Faculty of Economics, Universita degli Studi di Roma Tor Vergata, Rome, Italy; \\ Email: matteo.cristofaro@uniroma2.it

\section{Zhen Chen} \\ Department of Architecture, Faculty of Engineering, University of Strathclyde, Glasgow, United \\ Kingdom, Email: z.chen@live.com
}




\title{
Determining and Assessing the Risks of Commercial and Recreational Complex Building Projects in Developing Countries: A Survey of Experts in Iran
}

\begin{abstract}
Purpose: Since construction of Commercial and Recreational Complex Building Projects (CRCBPs) is one of the most important issues in many developing countries and requires a very high cost of implementation, it is important to identify and prioritize the risks of such projects. Therefore, the present study has attempted to identify and rank the risks of CRCBPs by studying the case of the "Hamedanian Memorial", a CRCBP in Iran.

Design/methodology/approach: To pursue this aim, a descriptive-survey method was used. The statistical population of the study consists of 30 experienced experts (consultants, contractors, and employers) of the "Hamedanian Memorial" project selected according to the Cochran formula and minimum population census. A questionnaire was used as the data collection tool, administered in all stages of risk identification and evaluation, and was devised by using library and field methods based on the literature and research background as well as interviewing experts in the risk identification and evaluation stages. Kendall's coefficient of agreement was used to validate the experts' opinions in the risk identification stage. The ranking in qualitative evaluation was done based on the risk intensity and the cumulative risk index.
\end{abstract}

Findings: The results show that the risks are associated with exchange rate fluctuation, inflation fluctuation, access to skilled workers, contractors' claims, and foreign threats from international relations.

Originality/value: The results and findings of the present study can be of interest to the executives of large commercial, leisure, public and private projects in developing and developed countries; understanding risks can significantly improve the decision making process of CRCBPs. 


\section{Introduction}

What are the main risks concerning Commercial and Recreational Complex Building Projects (CRCBPs)? Construction, like other industries, is influenced by risks from the beginning to the end of a project's lifecycle (Siu et al., 2018), mainly due to the inner uncertainty that is at the basis of the building process (Zavadskas et al., 2010). Risk in a project is pervasive and affects all activities. In theory, risk is simple and understandable, but, in practice, it turns into a complex problem that is controversial to measure. However, risk is based on the logic of losses and threats, but uncertainty is used to express risk that indicates the likelihood of occurrence of an event (Al-Bahar and Crandall, 1990). Therefore, prior to any action, investors and project managers must have a (intentionally) rational prediction and accurate assessment of project risks (Liu and Yang, 2006) - despite knowing that their perception may depend on inner socio-demographic or other inner features (Cristofaro, 2019; 2020; Cristofaro et al., 2020). Thus, identifying and evaluating risks in projects is necessary and can play a very important role in achieving project objectives.

In this regard, the risk management field offers some solutions for reducing risks associated with projects (Williams, 1995); basically involving a number of successive procedures that consist of implementing measures including time, cost, and quality to achieve project goals. As a consequence, following a policy and recommendations within a given framework leads project risk management to better performance in different phases of the project (Rodrigues-da-Silva and Crispim, 2014) by maximizing positive outcomes (opportunities) and minimizing negative consequences (threats) (PMI, 2017). Project management literature identified several tools and procedures for identifying and evaluating the risks involved in the construction industry. For example, Ezeldin and Orabi (2006) stated that the main reference in risk identification is historical data, past experience, and judgement. In addition, Hlaing et al. (2008) stated that there is no exact or standard procedure to identify risks in the construction industry; it relies strongly on the skills and judgement of 
the key project personnel. In this regard, various approaches can be used for risk identification. For example, Chapman (1998) believes that risk identification methods can be grouped into three general categories: $i$ ) identifying the risks by the risk analyst; $i$ ) risk identification by interviewing key members of the project team, and iii) risk identification through brainstorming meetings. In this regard, research has shown that the questionnaire survey is the most frequently used technique for risk identification in the construction sector (Hlaing et al., 2008; Goh et al., 2013; Marcelino-Sádaba et al., 2014).

A review of the research literature shows that, despite extensive studies to identify and evaluate the risks involved in the construction industry, few studies have been dedicated to the risks in CRCBPs. CRCBPs comprise a series of shops connected to each other with sidewalks that are designed and built alongside recreational, residential, office, hotel, restaurant and cinema spaces. Recently, new public investment has been in the development and construction of CRCBPs that has elements such as large investment, long-term return on investment as well as high risk and profit (Chen and Khumpaisal, 2009). In addition to meeting basic needs, these sectors have a positive impact on accelerating economic development (Kumaraswamy and Zhang, 2001). However, as with all projects, CRCBP projects may fail due to avoidable errors in the project phase, with the consequence of creating dramatic outcomes for the economics and society. The Jahan Nama amusement park in Isfahan, for example, has failed due to inadequate market studies as well as failure to comply with social norms and conditions (Ghaed and Daneshmandi, 2018). Therefore, identification, evaluation, and ultimately prioritization of the risks affecting the project objectives can mitigate the consequences of such failures and guarantee the success of the project in terms of size, cost, time and quality.

From the above and as initially stated, the present study aims at identifying, classifying, and evaluating the risks involved in CRCBPs projects. For this purpose, the "Hamedanian Memorial" project, a CRCBP in Isfahan (Iran), is studied. The research investigates the 
CRCBPs risks through conducting the Delphi method; the statistical population of the study consists of 30 experienced experts (consultants, contractors, and employers) of the "Hamedanian Memorial" project selected according to the Cochran formula and minimum population census. A questionnaire acted as the data collection tool, administered in all stages of risk identification and evaluation, and was devised by using library and field methods based on the literature and research background as well as interviewing experts in the risk identification and evaluation stages. Kendall's coefficient of agreement was used to validate the experts' opinions in the risk identification stage. The ranking in qualitative evaluation was done based on the risk intensity and the cumulative risk index. Findings of this research are an unprecedented contribution to the original body of CRCBPs and the construction industry. Such an outcome would enable decision makers to make more explanatory decisions with regard to, for example, proper risk allocation, bid pricing, selection of the optimum procurement route, and evaluation of different construction projects.

\section{Literature review}

The project lifecycle of a facility usually consists of the following phases: $i$ ) market demands or perceived needs (outcome: definition of project and objectives, and scope), ii) conceptual planning and feasibility study (outcome: conceptual plan for preliminary design), iii) design and engineering (outcome: construction plans for specifications), iv) procurement and construction (outcome: completion of construction), v) startup for occupancy (outcome: acceptance of facility), vi) operation and maintenance (outcome: fulfillment of useful life), and vii) disposal of facility (outcome: disposal). All of these phases are pervaded by uncertainty (Jordani, 2010; Eadie et al., 2013; Wetzel and Thabet, 2015) - thus, there is not sufficient information for their understanding and/or developments (Toma et al., 2012) which forms an integral and inevitable part of them (Perminova et al., 2008). Once more and more information on the project phases is collected, the decision makers are in risky 
situations or events, thus meaning their occurrence or evolution can be forecasted (Toma et al., 2012). Both uncertainty and risk result in deviation from the main objectives of projects and reduce their efficiency; therefore understanding and managing risks in projects is essential (Wideman, 1992). We, therefore, are opting for the 'risk' aspect due to the fact projects require that decision makers put effort into the understanding of project phases and their evolution. Uncertainties can be classified into four areas: i) uncertainty in a project's basics and estimates; ii) uncertainty in a project's design and logistics; iii) uncertainty in a project's objectives and priorities; and $i v$ ) uncertainty in relationships between entities in the project (Marinho et al., 2013). The risks in these four categories must be managed; in this regard, the purpose of risk and uncertainty management is to provide guidelines for a welldefined framework (PMI, 2017) and to address risk issues in both project opportunities and threats, to achieve greater success in projects.

The first step is to identify and record the characteristics of the risks (PMI, 2017) of the risks that may affect the project. Risk identification is an iterative process, as new risks may be identified and discovered as the project progresses through its lifespan (Sarvari et al., 2019b); in this vein, the definition of risk must be consistent throughout the project to facilitate comparison among the effects of risks in the project (PMI, 2017). Project management literature helped to build some risk identification tools and techniques, which include documentation review, brainstorming, the Delphi method, interviewing, checklists, hypothesis analysis, and graphing techniques (Zavadskas et al., 2010; Chan et al., 2014; Siu et al., 2018; Sarvari et al., 2019b; Zhou et al., 2020).

The second step is risk classification, considered as a key factor in risk management that greatly aids the process. Generally, classification includes cost, financing, demand, and political risks (Irimia-Diéguez et al., 2014), and should be managed to achieve the project objectives (Krane et al., 2010). Risks can be classified in different ways based on different purposes, such as their hierarchy (Wang and Tong, 2007) or impact on project goals 
(Wideman, 1992). However, the Project Management Institute (PMI) (2017) declares that, in order to identify and respond to risks, the most appropriate approach is to identify the risk groups based on their origin (rather than their impact), that is: external risks, internal risks, technical risks, and legal risks. This approach to the classification of risks is very close to the ones of Hillson et al. (2006) and Taroun (2014), who suggest an approach that identifies the groups and subgroups of risks that may occur in a typical project according to their origin this is the so-called Risk Breakdown Structure (RBS) (Hillson, 2003). One of the benefits of using this approach is that it highlights the many sources of risks and their relationships (PMI, 2017).

Some examples of the application of this approach are offered as follows. Sigmund and Radujković (2013) identified risks by designing an RBS composed of two categories, each with five sources: external (i.e., legal, political, economic, social, and natural) and internal (i.e., management, design, human, delivery, and contractual) (Sigmund and Radujković, 2013). In another study, Kolahan et al. (2015) identified different types of risks in electricity transmission projects in two major groups of postal and line projects. The results of this research led to the preparation of the RBS of these projects in four categories: legal, contractual, management and planning, and resource limitation. Nazari and Jaberi (2015) also used the RBS approach to identify risks in a large project-oriented industrial organization. They first identified the uncertainties associated with the projects by analyzing the characteristics of the projects under investigation. Then, by analyzing the identified risks and focusing on the designed RBS, they categorized the risks into five groups including technical and technology, cost and finance, project organization, contracts, and risks from outside the project's organization. Asgari et al. (2016) believed that, despite abundant software and hardware, risks in the upstream oil and gas industry have not been thoroughly investigated. They presented an RBS model, identifying risks at four different levels in six chapters, and 
the headings included political, economic, social, technological, technical, and organizational risks.

\subsection{Risk identification and classification in CRCBPs}

CRCBPs comprise a series of shops connected to each other with sidewalks designed and built alongside recreational, residential, office, hotel, restaurant and cinema spaces. Walewski and Gibson (2003) pointed out that CRCBPs are always high-risk mainly due to the huge amount of resources and stakeholders involved. In such projects, owners and contractors face risks that have an impact on time, performance, and cost targets, and risk management results in significant financial loss and prolongation of the project. Consequently, Walewski and Gibson (2003) highlighted the necessity to implement risk management approaches in CRCBPs. In this vein, over time, new tools for identifying risk in CRCBPs have been developed, as shown in the project management literature. Accordingly, Fuzzy methods have been extensively implemented - i.e., models that have the ability to recognize, represent, manipulate, interpret, and use vagueness and imprecise information - in risk identification in project management (Bandemer and Gottwald, 1995); however, scholars also embraced other approaches. Chatterjee et al. (2018), for example, applied a hybrid Multi Criteria Decision Method (MCDM) technique - models that help to evaluate multiple conflicting criteria in decision making - for risk identification in construction projects. In particular, these scholars identified risks and prioritized them based on a sensitivity analysis and a hybrid model based on the Analytic Network Process (ANP) method (i.e., a model that structures decisionmaking processes as a network) - that addressed the shortcomings of previous methods. In another study, Ezeldin and Ibrahim (2015) conducted risk analysis of a large CRCBP through a questionnaire distributed in Egypt and identified 30 risks, which were classified into six main categories. As a result, they found that the lack of financing, changes in design, incomplete specifications, and the lack of owner liquidity were the most important risks. 


\section{Research methodology}

In order to achieve the identified research aim, an empirical study of the CRCB "Hamedanian Memorial" project, set in Iran, has been undertaken (see Obermeyer Planen and Beraten GMBH, 2016). In particular, it has been investigated the risk identification and classification for this project has been investigated, as pointed out in Figure 1. In particular, the implemented method has followed these steps: 1) Risk identification and categorization, and 2) Risk assessment.

\section{Figure 1: Research Methodology of the Study}

As pointed out in Figure 1, the method of data collection in this study is based on a combination of field and library methods. Given the nature of risk management, identification and evaluation of risks by analyzing the data collected are deemed a systematic approach that provides a better understanding of the phenomena. For this reason, the field data collection method proves effective in the present research, but, in some cases, it is necessary to use other existing databases and resources to obtain information for developing new theories accordingly. Thus, the library method is also be used in this study. Many researchers have used this combined approach to identify the risks in construction projects, i.e. Siu et al. (2018) and Sarvari et al. (2019a).

The statistical population of this study consists of 30 experienced experts (detailed later) with specialized viewpoints from all groups involved in the project (consultants, employers, and contractors). A questionnaire pointing out the main risks of CRCBPs has been prepared based on the results presented by existing risk management literature. Opinions were used from a group of experts to form a decision matrix both in the process of risk identification and in the qualitative assessment of risks. 


\subsection{Data collection}

To reach the goal of this study, a Delphi research method (Yeung et al., 2007; Olawumi and Chan, 2018) was implemented aimed at collecting the views of the experts of infrastructure projects about the challenges that developing countries have to face in order to attract private investments. In particular, the data collection method consisted of a questionnaire and semistructured interviews administered to the following experts: contractors, consultants, and employers (similar to Olawumi and Chan, 2019). The Delphi process is a perspective and systematic research method to obtain comments from a group of experts on a specific subject or question. In particular, the Delphi process has a structure to predict and help decision making through a three-round survey that encompasses data gathering and concludes with group agreement. The Delphi includes survey or questionnaire rounds using a basic questionnaire, from which questionnaires are formed for the next rounds. Yet, Delphi keeps the responders anonymous and hides each answer from other responders on the panel (Chan and Chan, 2012; Olawumi and Chan, 2019). Most of the time, sampling is based on a used target and agent samples are not important, but the quality, rather than the number, of panelists is more important (Chan and Chan, 2012; Olawumi and Chan, 2019). From that, participants of the Delphi are experts, critics and panelists who must have knowledge and experience in a same subject, time to participate, and effective communication skills (Yeung et al., 2007). There is no explicit or firm rule on how to choose and how many experts to choose for the Delphi process. The number of the responders, indeed, depends on the factors of homogeneous and heterogeneous types of the sample, target of the Delphi, duration of data gathering, domain of the problem, and acceptability of the answer (Chan et al., 2007; 2010; Chan and Choi, 2015). The number of participants is usually less than 50 and most of the time is around 15 to 20 (Sarvari et al., 2019b).

In the present study, all experts and experienced individuals with specialized opinions from all groups of the "Hamedanian Memorial" CRCBP (i.e., consultants, employers, and 
contractors), based on a census of up to 30 people, were considered as sample size. It should be noted that the panel size used in this study is bigger than that of previous similar contributions, which had 19 (Choi et al., 2010) and 12 (Salman et al., 2007) respondents.

\section{Table 1: Details of interviewed experts}

Demographic findings of this study indicated that: a) $90 \%$ of respondents are male, $b$ ) respondents aged 30-45 years accounted for 50\% of the total statistical population, $c$ ) respondents with a Bachelor's degree accounted for $46.7 \%$, d) respondents with over 20 years' work experience accounted for $43.3 \%, e$ ) the majority of respondents $(70 \%)$ work for private entities, f) $53.3 \%$ acted as consultants for the CRCBP, and $g$ ) the majority of respondents $(23.3 \%)$ has an engineering specialization in terms of functional background. It is worth noticing that the three categories indicated at point $f$ ) correspond to the so-called ‘trilateral governance' of projects (Reve and Levitt, 1984; Dadzie et al., 2012; Memon et al., 2014); from that, the substantial presence of all these three categories ensures that the main project stakeholders' opinions are taken into consideration.

\subsection{Survey questionnaire}

The type of data collection tool is subject to various factors including the nature and method of the research. Questionnaire was selected as the data collection tool in this research, similar to other studies (Chan et al., 2014; Ezeldin and Ibrahim, 2015; Sarvari et al., 2019a). The questionnaire was designed based on the initial RBS, which is mainly based on past research and library studies, and it was used to identify and document the risks of CRCBPs - using the Delphi technique as one of the most common methods of risk identification (Rostami, 2016; Sarvari et al., 2019b; Siraj and Fayek, 2019). 


\section{Table 2: Identified risks affecting the objectives of RCPs based on the review of the literature}

Table 2 outlines the risks affecting the objectives of CRCBPs and categorizes them into internal and external risks as well as grouping them into 14 clusters at the second level (i.e., social, economic, political, legal, natural, technical, work force, investment, management, safety, design, contract, market, and environmental) and 53 risks at the third level. Due to different uses in previous studies and because the risks of each project vary widely depending on the environmental and social conditions, the present study uses past records and library studies as well as interviewing reporters in order to design a comprehensive RBS for CRCBPs.

Considering the 53 risks identified in CRCBPs, the experts expressed their opinions about them by using the Delphi technique. After statistical analysis, the results show that the majority of the 53 items were in collective agreement; however, based on the experts' opinions, the risks relate to the tactical group and two risk items of the market group including growth and job competition, and changes in demand for purchasing spaces - are eliminated. On the other hand, tax risks in the economic group, inappropriate financing in the investment group, inaccurate distribution of funds, unrealistic goals in the management group, accessibility of the site, and traffic permits from the environmental group are added to the list. Finally, a questionnaire with 55 items was sent to the experts for evaluation.

At this stage, 49 out of the 55 items were validated: tax risks, political events, changes in government attitudes, inadequate geotechnical studies, failure to identify underground factors, and workshop supervision were eliminated. In contrast, 33 new items were added to the list of the risks. For example, differences in cultural levels of people, regional and ethnic constraints, bank interest rate fluctuations, import regulations, government destabilization, inappropriate government relations, accidents caused by unexpected factors in the electricity distribution network, accidents of the unforeseen factors in the water and wastewater 
network, mismatch of the spaces for clients' needs, public lack of interest towards projects, increased competitiveness by other rival projects, change in demand for different user space, lack of proper organizational coordination, project staff crises in different units, assignment of responsibility of units to third parties, incompatibility of the design with a project site, inaccuracies in calculations and unrealistic estimates, incompatibility with design codes, and neglecting maintenance periods. At the end of this process, 82 items were considered as risks and experts concluded that all 82 factors could be identified as a risk in CRCBPs.

On the one hand, the elimination and addition of items by the experts suggests that eliminated items are in conflict with the objectives of the project. On the other hand, the added items are in line with the project objectives, and these are evaluated by the experts in the next stage.

\subsection{Validity and reliability of research tools}

The validity and reliability of the Delphi method are not so easy to control and the method has been heavily criticized for lack of reliability (Skulmoski et al., 2007). In other words, if the experts were given similar information or questions, it is highly possible to obtain different results. The validity of the technique has also been criticized because the researcher does not have any influence on the development and preparation of the questionnaire or tools, whereas he/she affects the formal validity. However, the validity of the content is guaranteed if the participants are representative of the target group. Therefore, in the present study the opinions of 30 experts have been collected including academic experts, project managers, senior project consultants, employers, contractors, and project management experts. Content validity was evaluated by the Lavshh method and Kendall's coefficient of agreement was used to assess the degree of agreement:

$C V R=\frac{\left(\text { ne }-\frac{\mathrm{N}}{2}\right)}{\frac{\mathrm{N}}{2}}$ 
Where, CVR (content validity ratio) is the ratio of content validity, ne is the number of experts who approved the suitability of items included in the questionnaire, and $N$ is the total number of participants.

As mentioned earlier, 30 experts were asked to give their opinions about the identified risks in order to determine whether the 53 factors identified could be considered as risks in CRCBPs or not. The frequency of each expert's agreement with the questionnaire items was determined and then content validity of the questionnaire was calculated.

\section{Table 3: Expert numbers and minimum size in content validity}

The validity was compared with Table 3, which shows the minimum size and number of experts in content validity. The results indicated that most of the items were valid. However, according to the experts' opinions, it was necessary to remove a number of technical and market risks and add new questions, such as tax and toll risks, site access and traffic permits. Next, a new questionnaire with 55 items was sent to the experts. At this stage, the majority of the 55 items were valid, but again it was necessary to remove some of the disagreements and include new items that eventually led to the addition of new items to the questionnaire. Therefore, in the following step, the new questionnaire was sent back to the experts with 82 items.

\section{Table 4: Evaluating content validity of each risk factor of questionnaire by Lavshh formula}

At this stage, all the experts concluded that the 82 items could be identified as risks in the CRCBPs. Content validity was estimated as equal to 0.99 at this stage. Since the obtained CVR was higher than the minimum value, it can be concluded that the items and questionnaire reached a high content validity. Table 3 shows the validity of each item of the questionnaire using the Lavshh formula. 


\subsection{Evaluation of consensus scale}

Kendall's coefficient of agreement was used to investigate the coefficient of agreement with the Delphi method. Kendall's coefficient of agreement is a measure of coherence and agreement between several categories related to the $N$ objects or individuals. In fact, by using this scale, one can find the rank correlation between the $K$ sets. Such a measure is particularly useful in investigating the validity of judgments; indeed, Kendall's coefficient of agreement indicates that people who have prioritized categories according to their importance have essentially applied the same criteria to judge the importance of each category, and thus agree with one another in that regard. This scale is calculated using the following formula:

$$
W=\frac{\mathrm{S}}{\frac{1}{12} \mathrm{k}^{2}\left(\mathrm{~N}^{3}-\mathrm{N}\right)}
$$

Where $\mathrm{S}=\sum\left[\mathrm{R}_{\mathrm{j}}-\frac{\sum \mathrm{R}_{\mathrm{j}}}{\mathrm{N}}\right]^{2}, R_{j}$ is the rank set for a given factor, $K$ is the number of rank sets, and $N$ is the number of ranked factors.

The scale ranges from zero to one, indicating the degree of consensus reached by the Delphi panel (very strong consensus: $W<0.9$, strong consensus: $W=0.7$, moderate consensus: $W=0.5$, poor consensus: $W=0.3$, and very poor consensus: $W=0.1)$. It is worth noting that the $W$ coefficient is not significant enough to stop the Delphi process. For panels consisting of more than 10 members, even very small values of $W$ are considered significant. Kendall's coefficient in the present study was calculated equal to 0.91 , which indicates a very strong consensus and favorable agreement among the respondents.

\subsection{Qualitative evaluation of risks}

In order to prioritize the risks in a qualitative way, the severity of the impact of each risk has been taken into account - which is calculated by multiplying the probability of occurrence of each risk by its impact on the project objectives. For this purpose, a Primary Risk Index $(P R I)$ 
is defined based on the criteria for the probability of occurrence of the risk and the extent to which the risk affects the objectives of the "Hamedanian Memorial" project. These objectives include the time, cost and quality of the project.

$P R I=\sum\left(P \times I_{t}\right)+\left(P \times I_{c}\right)+\left(P \times I_{q}\right)$

In which $P$ is the probability of occurrence of risk and $I_{t}, I_{c}$, and $I_{p}$ is the intensity of impact of the risk on the project time, cost, and quality, respectively.

These indices were analyzed separately based on the opinions of each expert, and later, the $P R I_{1}$ to $P R I_{30}$ indices are determined for each of the 82 identified risks. The indices are calculated using the arithmetic mean method and the cumulative risk index for each of the risks using the following relationship:

$\mathrm{APRI}=\frac{\sum_{\mathrm{i}=1}^{30}\left(P R I_{\mathrm{i}}\right)}{\mathrm{N}}$

Where $A P R I$ is the cumulative risk index for each of the 82 identified risks, $P R I_{\mathrm{i}}$ is the primary index risk for each individual, and $N$ is the total number of experts who participated in this research. It is then possible to rank the risks using this index. It is evident that a simple and primitive definition of risk, i.e. the probability of occurrence multiplied by the risk impact, is included in the PRI index and, thus, in the APRI index. However, the scope of impact is expanded to cost, time and quality criteria with equal weight.

\section{Discussion of survey results}

\subsection{Risk identification}

The purpose of risk identification is to identify and record the details of the largest number of uncertain events before they occur. This facilitates proper management of risks at the time of their occurrence. However, it is not always possible to identify all risks for reasons such as 
lack of knowledge, emerging risks, future risks, hidden risks, and so on. In the present study, the Delphi method was used to reach consensus among respondents regarding the proposed risk items of CBCRPs through the RBS. Finally, with the consensus of the experts, the 82 risks were identified and recorded.

Kendall's coefficient of agreement was used to evaluate the experts' agreement in the Delphi method. Kendall's coefficient of agreement indicates that experts who have prioritized categories according to their importance, have essentially used the same criteria to judge the importance of each category, and thus agree with each other. Based on the calculations, Kendall's coefficient of agreement was determined as equal to 0.91 , implying a very strong consensus among experts who participated in the risk identification process.

\subsection{Results of evaluation and qualitative prioritization of risks}

As stated in the literature review (Liu and Yang, 2006; Siu et al., 2018), risk is a nondeterministic phenomenon that may affect the project objectives upon its occurrence. This can be interpreted in two ways: the first is the influence on the objectives of the project, and the second is the uncertainty and probability of the event. The magnitude and significance of each risk depends entirely on the two factors mentioned, and these two factors must be fully evaluated to obtain a clear understanding of the impact of each risk. Therefore, qualitative evaluation was based on both probability of occurrence and impact of each risk.

Comprehensive qualitative prioritization methods based on the source of risk were performed using the RBS (Al-Bahar and Crandall, 1990). By determining the probability of occurrence of each risk and its impact on the project objectives, it is possible to calculate the $P I$ score. After calculating the PI, the score of each area of RBS is calculated in terms of the sum of PI scores. In order to achieve the desired outcome, after determining the probability of occurrence of each risk and its impact on the project time, cost and quality, the PRI was 
calculated according to the explained Eq. (3) already described. It is worth noting that the index was calculated on a case-by-case basis according to each expert's opinion.

Then, $P R I_{1}$ to $P R I_{30}$ were determined for each of the 82 risks, and the cumulative risk index for each of the risks was calculated by Eq. (5):

$$
\begin{aligned}
& P R I=\sum\left(\mathrm{P} \times \mathrm{I}_{\mathrm{t}}\right)+\left(\mathrm{P} \times \mathrm{I}_{\mathrm{c}}\right)+\left(\mathrm{P} \times \mathrm{I}_{\mathrm{q}}\right) \\
& A P R I=\frac{\sum_{\mathrm{i}=1}^{30}\left(P R I_{\mathrm{i}}\right)}{\mathrm{N}}
\end{aligned}
$$

\section{Table 5: Expert opinions on Probability and Impact of risks}

Expert opinions were obtained in accordance with Table 5.

\section{Table 6: Calculation of PRI based on the Probability and Impact of risks}

According to Table 6, the PRI value was calculated for each risk. By calculating the PRI of all risks and based on the experts' opinions, the APRI value was calculated and prioritization was carried out.

\section{Table 7: $P R I$ and $A P R I$ results of qualitative risk evaluation}

Table 7 summarizes the results of $P R I$ and APRI risks and the rank grade of each risk. As is evident, by performing the qualitative assessment and taking into account the timing condition of data collection, currency rate fluctuations and inflation rate fluctuations from the economic risks group were ranked first and second, respectively. According to the experts' opinions, availability of skilled workers from the work force group ranked third, construction contractor claims from the construction risks group ranked fourth, and foreign threats due to international relations from the political risks group ranked fifth. Finally, accidents due to unpredicted factors in the water and wastewater network from the accidents risks group was the least important risk. 


\section{Conclusions and implications}

This study aimed to identify and prioritize risks in Commercial and Recreational Complex Building Projects (CRCBPs). The statistical population of the study consisted of 30 experts from all groups involved in the "Hamedanian memorial" project (consultants, employers, and contractors), who were selected carefully in order to very accurately represent all of the the participants to the project. The initial identification of risks was carried out by surveying the previous research with scrutiny. In the next step, for the purpose of identification and qualitative prioritization of risks in CRCBPs, a semi-structured questionnaire was prepared in order to collect experts' opinions. By reviewing and summarizing past research and doing further research using library studies, the RBS was formulated in three levels. By using the Delphi technique as an effective and useful method of identifying risks, the proposed risks in one CRCBP were reviewed by experts. Finally, the degree of agreement of the experts' opinions was evaluated using Kendall's coefficient of agreement, and based on the analysis, 82 risks were identified. These were then categorized into internal and external risks in 16 groups: social, economic, political, legal, accidents, market, workforce, investment, management, project communication, design, construction, timetable, exploitation, environmental, and logistics. The risks were prioritized based on their probability of occurrence and impact on the project's objectives. Finally, the score of each RBS area was calculated based on the sum of $P R I$ scores, and the prioritization of risks was done based on the cumulative primary risk index $A P R I$.

The qualitative prioritization results showed that the top 10 risks in CRCBPs are currency exchange rate fluctuations, inflation rate fluctuations, access to skilled labor, contractor claims, foreign threats from international relations, bank interest rate fluctuations, lack of qualified consultants, traffic permits, unrealistic primary estimation, and the condition of adjacent buildings. Among these ten risks, some are external and some other internal to the CRCBP, but all of them can significantly influence its development according to the setting 
(e.g., being implemented in a developed or developing country). Some external risks, i.e., currency exchange rate fluctuations, inflation rate fluctuations, foreign threats from international relations, and bank interest rate fluctuations, cannot be managed by those responsible for CRCBPs, and also they can have a great impact (especially) on the lifecycle phase of a project's conceptual planning and feasibility study. Indeed, if these economic and financial risks have a manifestation in the early phases of the project, CRCBP decision makers can decide to abandon it with the hope of not having already invested too much. Alternatively, decision makers can try avoiding these risks by reverting to an insurance against CRCBPs' economic and financial risks. This insurance would be even more acceptable financially if those responsible for the CRCBP had also already invested in other projects. The increase in a project's volume allows those in authority to control investments with different degrees of risk manifestation and, in practice, reduce the risk of overall failure. The insurance protection, however, cannot work for the risks with traffic permits and the condition of adjacent buildings - which are always outside the control of the projects' management team. These risks, if verified, can respectively delay the CRCBP (or undermine its fruition) and decrease the value of the CRCBP. In these cases, CRCBP decision makers can choose between continuing the project while trying to maintain the economic and financial equilibrium or liquidating it if these risks heavily affect the possibility of reaching the planned return on investments. Finally, the risks of lack of access to skilled labor, lack of qualified consultants, and unrealistic primary estimation can have as great an impact as the previous ones - by delaying the execution of the CRCBP as well as undermining its management and coordination. However, at the same time, because they are related to processes activated by CRCBP management, they can be directly controlled. Indeed, the lack of access to resources or qualified consultants can be usually solved by relying on human resource agencies, headhunters, or other qualified players that are able to identify suitable employees or consultants for the CRCBP. The same solution applies for the unrealistic 
primary estimation, which can compromise the feasibility study of the CRCBP; indeed, employing skilled labor and qualified consultants should minimize forecasting mistakes by the management team.

The findings of this study are consistent with previous research. Indeed, the results presented are similar to the ones of Zavadskas et al. (2010), who found that risk indicators in construction projects are mainly related to the domestic and international changes, a country's economic efficiency, workforce, construction characteristics, and consultative and contractual services, as the top priorities in dealing with project risks. In another study, Chen and Khumpaisal (2009) used the ANP method to prioritize a group of risk assessment criteria against social, economic, environmental, and technological requirements directly related to commercial real estate development. The results of their research are consistent with the present study.

The results of the research are useful for the beneficiaries of the project by giving special attention to risks with the highest contribution to the performance of the project during its lifecycle in order to ensure that the main objectives of the project are met. In this regard, among the risks identified in this study, the risk of exchange rate fluctuations has a significant impact on all project objectives; therefore, implementing projects in countries and/or periods where the exchange rate is stable facilitates the achievement of project objectives. However, it is also true that project risks vary from time to time depending on the project progress (Jaafari, 2001; Perroni et al., 2015), and this is even more true for financial risks, such as the instability of exchange rate, that can suddenly vary due to unforeseen phenomena (Froot, 2008) - especially external ones. From that, by considering the project lifecycle of a facility (Jordani, 2010; Eadie et al., 2013; Wetzel and Thabet, 2015), the influence of identified groups of risks cannot be exclusively studied in some phases of the CRCBP. Indeed, if looking at, for example, the 'Management' category of risks, the individual risks that compose it can be important for different or for multiple phases of the CRCBP's lifecycle. 
This is the case of the 'Site unavailability and delay in delivery of land to the presenter', that surely appears more within the first phases of the CRCBP rather than in the concluding ones, or the case of the 'Poor coordination and management', which is an important risk in all CRCBP phases (e.g., design and engineering, and procurement and construction). From the foregoing, practitioners should: i) mitigate single risks that are more likely (but not exclusively) to occur in each phase of the CRCBP's lifecycle, ii) control the evolution of risks and effects on project performance, even if the project passed the phase in which they were expected to have a manifestation, by using, for example, the real options method or a scenario-based approach (Chen et al., 2009; Bañuls et al., 2017). In sum, external and internal conditions of a CRCBP may vary and risks that were thought as not very likely to occur can suddenly appear; because of that, practitioners should maintain a high level of attention on risks and changes in the internal and external environment and be prepared for their manifestation (Cristofaro, 2017).

The main limitation of this study lies in the small sample of experts interviewed, even though they can surely be considered as suitable, in line with the aim of the study. Future studies should enhance the validity of the proposed results, either through increasing number of experts to be interviewed and through the replication of the presented study in other developing countries. In addition, it would be interesting to compare the results emerging from developing countries with those of developed ones in order to identify similarities and differences. Moreover, the socio-demographic characteristics of experts who determined and assessed risks of CRCBPs may have a role in directing their own attention to the identification of particular risks rather than others and in assigning a greater importance to them. In this regard, it would be interesting to investigate, in a quantitative manner and building on the Upper Echelons Theory literature (Abatecola and Cristofaro, 2015; 2020), whether socio-demographic characteristics and/or other psychological variables are significant in the definition and evaluation of CRCBP risks at the individual and group level. 


\section{References}

Abatecola, G. and Cristofaro, M. (2015), "Upper echelons and executive profiles in the construction value chain: evidence from Italy", Project Management Journal, Vol. 47 No. 1, pp.13-26.

Abatecola, G. and Cristofaro, M. (2020), "Hambrick and Mason's "Upper Echelons Theory": evolution and open avenues", Journal of Management History, Vol. 26 No. 1, pp.116136.

Al-Bahar, J.F. and Crandall, K.C. (1990), "Systematic risk management approach for construction projects", Journal of Construction Engineering and Management, Vol. 116 No. 3, pp.533-546.

Asgari, M.M., Sadeghi, M. and Seifloo S. (2016), "Identifying and prioritizing the risks of high-power oil and gas projects in Iran using risk breakdown structure and TOPSIS technique", Journal of Economic Research and Policies. Vol. 24 No. 78, pp.96-57. (In Persian).

Bandemer, H. and Gottwald, S. (1995), Fuzzy sets, fuzzy logic, fuzzy methods, Wiley, Chichester.

Bañuls, V.A., López, C., Turoff, M. and Tejedor, F. (2017), "Predicting the impact of multiple risks on project performance: a scenario-based approach", Project Management Journal, Vol. 48 No. 5, pp.95-114.

Chan, D.W.M., Chan, A.P., Lam, T.I.P. and Chan, H.L. (2010), "Exploring the key risks and risk mitigation measures for guaranteed maximum price and target cost contracts in construction", Construction Law Journal, Vol. 26 No. 5, pp.364-378.

Chan, D.W., Chan, A.P., Lam, T.I.P., Lam, W.M.E. and Wong, J.M. (2007), "Evaluating guaranteed maximum price and target cost contracting strategies in Hong Kong construction industry", Journal of Financial Management of Property and Construction, Vol. 12 No. 3, pp.139-150.

Chan, D.W.M. and Chan, J.H.L. (2012), "Developing a Performance Measurement Index (PMI) for Target Cost Contracts in Construction: a Delphi Study", Construction Law Journal, Vol. 28 No. 8, pp.590-613.

Chan, D.W.M. Chan, J.H.L. and Ma, T. (2014), "Developing a fuzzy risk assessment model for guaranteed maximum price and target cost contracts in South Australia", Facilities, Vol. 32 No. 11/12, pp.624-646.

Chan, D.W.M. and Choi, T.N.Y. (2015), "Critical analysis of the application of the Safe Working Cycle (SWC)”, Journal of Facilities Management, Vol. 13 No. 3, pp.244-265.

Chapman, R.J. (1998), "The effectiveness of working group risk identification and assessment techniques", International Journal of Project Management, Vol. 16 No. 6 , pp.333-343.

Chatterjee, K., Zavadskas, E.K., Tamošaitienè, J., Adhikary, K. and Kar, S. (2018), “A hybrid MCDM technique for risk management in construction projects”, Symmetry, Vol. 10 No. 2, pp.46. 
Chen, T., Zhang, J. and Lai, K.K. (2009), “An integrated real options evaluating model for information technology projects under multiple risks", International Journal of Project Management, Vol. 27 No. 8, pp.776-786.

Chen, Z. and Khumpaisal, S. (2009), "An analytic network process for risks assessment in commercial real estate development", Journal of Property Investment \& Finance, Vol. 27 No. 3, pp.238-258.

Choi, J.H., Chung, J. and Lee, D.J. (2010), "Risk perception analysis: participation in China's water PPP market", International Journal of Project Management, Vol. 28 No. 6, pp.580-592.

Cristofaro, M. (2017), "Reducing biases of decision-making processes in complex organizations", Management Research Review, Vol. 40 No. 3, pp.270-291.

Cristofaro, M. (2019), "The role of affect in management decisions: a systematic review", European Management Journal, Vol. 37 No. 1, 6-17.

Cristofaro, M. (2020), "I feel and think, therefore I am: an Affect-Cognitive Theory of management decisions", European Management Journal, Vol. 38 No. 2, pp.344-355.

Cristofaro, M., Giardino, P.L. and Leoni, L. (2020), "The influence of core self-evaluations on group decision making processes: a laboratory experiment", Administrative Sciences, Vol. 10 No. 2, p.29.

Dadzie, J., Abdul-Aziz, A.R. and Kwame, A. (2012), "Performance of consultants on government projects in Ghana: client and contractor perspective", International Journal of Business and Social Research, Vol. 2 No. 6, pp.256-267.

Eadie, R., Browne, M., Odeyinka, H., McKeown, C. and McNiff, S. (2013), "BIM implementation throughout the UK construction project lifecycle: an analysis", Automation in Construction, Vol. 36, pp.145-151.

Ezeldin, A.S. and Orabi, W. (2006), "Risk identification and response methods: views of large scale contractors working in developing countries", In Pandey, M., Wei-Chau, M.X. and Lei, X. (Ed.s.), Advances in Engineering Structures, Mechanics \& Construction, Springer, Dordrecht, pp.781-792.

Ezeldin, S. and Ibrahim, H.H. (2015), "Risk analysis for mega shopping mall projects in Egypt”, Journal of Civil Engineering and Architecture, Vol. 9, pp.644-651.

Froot, K.A. (2008), "The intermediation of financial risks: evolution in the catastrophe reinsurance market”, Risk Management and Insurance Review, Vol. 11 No. 2, pp.281294.

Ghaed, R.S. and Daneshmandi, N. (2018). "Analysis of Urban Tourism Spatial Pattern (Case Study: urban tourism space of Isfahan city)", Human Geography Research Quarterly, Vol. 50 No.4, pp.945-961.

Goh, C.S., Abdul-Rahman, H. and Abdul Samad, Z. (2013), “Applying risk management workshop for a public construction project: case study", Journal of Construction Engineering and Management, Vol. 139 No.5, pp.572-580.

Hillson, D. (2003), "Using a risk breakdown structure in project management", Journal of Facilities Management, Vol. 2 No. 1, pp.85-97. 
Hillson, D., Grimaldi, S. and Rafele, C. (2006), "Managing project risks using a cross risk breakdown matrix", Risk Management, Vol. 8 No. 1, pp.61-76.

Hlaing, N.N., Singh, D., Tiong, R.L.K. and Ehrlich, M. (2008), "Perceptions of Singapore construction contractors on construction risk identification", Journal of Financial Management of Property and Construction, Vol. 13 No. 2, pp.85-95.

Irimia-Diéguez, A.I., Sánchez Cazorla, Á. and Alfalla Luque, R. (2014), "Risk management in megaprojects", Procedia: Social and Behavioral Sciences, Vol. 119, pp.407-416.

Jaafari, A. (2001), "Management of risks, uncertainties and opportunities on projects: time for a fundamental shift", International Journal of Project Management, Vol. 19 No. 2, pp.89-101.

Jordani, D.A. (2010), "BIM and FM: the portal to lifecycle facility management", Journal of Building Information Modeling, Spring, pp.13-16.

Kolahan, F., Rezayinik, E. Ramezanpour, H., Hassani Doughabadi, M., and Tajadod A. (2015), "Identifying and prioritizing the risks of power industry development projects in Iran”, Journal of Industrial Engineering, Vol. 49 No.1, pp.107-116 (In Persian).

Krane, H.P., Rolstadås, A. and Olsson, N.O. (2010), "Categorizing risks in seven large projects-which risks do the projects focus on?", Project Management Journal, Vol. 41 No. 1, pp.81-86.

Kumaraswamy, M.M. and Zhang, X.Q. (2001), "Governmental role in BOT-led infrastructure development”, International Journal of Project Management, Vol. 19 No. 4, pp.195-205.

Liu, P. and Yang, D.L. (2006), "Research on Risk Evaluation of Shopping mall Investment", available at: http://www.irbnet.de/daten/iconda/CIB5849.pdf (accessed 18 March 2019)

Marcelino-Sádaba, S., Pérez-Ezcurdia, A., Lazcano, A.M.E. and Villanueva, P. (2014), "Project risk management methodology for small firms", International Journal of Project Management, Vol. 32 No. 2, pp.327-340.

Marinho, M., Sampaio, S. and Moura, H. (2013), "An approach related to uncertainty in software projects", International Conference on Systems, Man, and Cybernetics, Manchester, UK, 13-16 October, IEEE, pp.894-899.

Memon, A.H., Rahman, I.A., Akram, M. and Ali, N.M. (2014), "Significant factors causing time overrun in construction projects of Peninsular Malaysia", Modern Applied Science, Vol. 8 No. 4, pp.16-28.

Nazari, A. and Jaberi, M. (2015), "Project risk identification by designing a risk fracture structure design case study: project-based industrial organization", International Journal of Industrial Engineering and Production Management, Vol. 1, (In Persian).

Obermeyer Planen and Beraten GMBH (2016), Master plan studies of Hamedanian Memorial project, available at: https://www.opb.de/pdfs/Company_Profile/pubData/source/Company_Profile.pdf (accessed 23 March 2019). 
Olawumi, T.O. and Chan, D.W.M. (2018), "Identifying and prioritizing the benefits of integrating BIM and sustainability practices in construction projects: a Delphi survey of international experts", Sustainable Cities and Society, Vol. 40, pp.16-27.

Olawumi, T.O. and Chan, D.W.M. (2019), "Critical success factors for implementing building information modelling and sustainability practices in construction projects: a Delphi survey", Sustainable Development, Vol. 27 No. 4, pp.587-602.

Perminova, O., Gustafsson, M. and Wikström, K. (2008), "Defining uncertainty in projects-a new perspective", International Journal of Project Management, Vol. 26 No. 1, pp.7379.

Perroni, M., Dalazen, L.L., Da Silva, W.V., Gouvêa, S. and Da Veiga, C.P. (2015), "Evolution of risks for energy companies from the energy efficiency perspective: the Brazilian case", International Journal of Energy Economics and Policy, Vol. 5 No. 2, pp.612-623.

Project Management Institute (PMI) (2017), A guide to the project management body of knowledge: $\mathrm{PMBOK}^{\circledR}$ Guide, 6th ed, Project Management Institute, Newton Square, PA, USA.

Reve, T. and Levitt, R.E. (1984), "Organization and governance in construction", International Journal of Project Management, Vol. 2 No. 1, pp.17-25.

Rodrigues-da-Silva, L.H. and Crispim, J.A. (2014), "The project risk management process, a preliminary study", Procedia Technology, Vol. 16, pp.943-949.

Rostami, A. (2016), "Tools and techniques in risk identification: a research within SMEs in the UK construction industry", Universal Journal of Management, Vol. 4 No. 4, pp.203210.

Salman, A.F., Skibniewski, M.J. and Basha, I. (2007), "BOT viability model for large-scale infrastructure projects", Journal of Construction Engineering and Management, Vol. 133 No. 1, pp.50-63.

Sarvari, H., Rakhshanifar, M., Tamošaitienè, J., Chan, D. W. and Beer, M. (2019a), “A risk based approach to evaluating the impacts of zayanderood drought on sustainable development indicators of riverside urban in isfahan-iran", Sustainability, Vol. 11 No. 23 , pp.6797.

Sarvari, H., Valipour, A., Yahya, N., Noor, N., Beer, M. and Banaitiene, N. (2019b), "Approaches to risk identification in public-private partnership projects: Malaysian private partners' overview”, Administrative Sciences, Vol. 9 No. 1, pp.17.

Sigmund, Z. and Radujković, M. (2013), "Risk breakdown structure for construction projects on existing buildings”, Procedia-Social and Behavioral Sciences, Vol. 119, pp.894-901.

Siraj, N.B. and Fayek, A.R. (2019), "Risk identification and common risks in construction: literature review and content analysis", Journal of Construction Engineering and Management, Vol. 145 No. 9, 03119004.

Siu, F.M.F., Leung, J.W.Y. and Chan, D.W.M. (2018), “A Data-driven approach to identifyquantify-analyse construction risk for Hong Kong NEC projects", Journal of Civil Engineering and Management, Vol. 24 No. 8, pp.592-606. 
Skulmoski, G.J., Hartman, F.T. and Krahn, J. (2007), "The Delphi method for graduate research", Journal of Information Technology Education: Research, Vol. 6 No. 1, pp 121.

Taroun, A. (2014), "Towards a better modelling and assessment of construction risk: insights from a literature review", International Journal of Project management, Vol. 32 No. 1, pp.101-115.

Toma, S.V., Chiriţă, M. and Şarpe, D. (2012), "Risk and uncertainty", Procedia Economics and Finance, Vol. 3, pp.975-980.

Walewski, J. and Gibson, G. (2003), "International project risk assessment: methods, procedures, and critical factors", available at: http://citeseerx.ist.psu.edu/viewdoc/download?doi=10.1.1.579.3266\&rep=rep1\&type=pd f (accessed 24 March 2019)

Wang, H. and Tong, Y. (2007), "Algorithm study on models of multiple objective risk decision under principal and subordinate hierarch decision-making", Operations Research and Management Science, Vol. 16 No. 1, pp.1-8.

Wetzel, E.M. and Thabet, W.Y. (2015), "The use of a BIM-based framework to support safe facility management processes", Automation in Construction, Vol. 60, pp.12-24.

Wideman, R.M. (1992), A guide to managing project risks and opportunities, Project Management Institute Inc., Pennsylvania, PA.

Williams, T. (1995), “A classified bibliography of recent research relating to project risk management”, European Journal of Operational Research, Vol. 85 No. 1, pp.18-38.

Yeung, J.F.Y., Chan, A.P.C., Chan, D.W.M. and Li, L.-K. (2007), "Development of a Partnering Performance Index (PPI) for construction projects in Hong Kong: a Delphi study", Construction Management and Economics, Vol. 25 No. 12, pp.1219-1237.

Zavadskas, E.K., Turskis, Z. and Tamošaitiene, J. (2010), "Risk assessment of construction projects”, Journal of Civil Engineering and Management, Vol. 16 No. 1, pp.33-46.

Zhou, H., Zhao, Y., Shen, Q., Yang, L. and Cai, H. (2020), "Risk assessment and management via multi-source information fusion for undersea tunnel construction", Automation in Construction, Vol 111, pp.103050. 
Table I: Details of interviewed experts

$\begin{array}{lll}\text { Socio-demographic characteristics } & \text { No. } & \%\end{array}$

\section{Gender}

- Male

- Female

$27 \quad 90 \%$

Age (in years)

- $<30$

- $30-45$

3

$10 \%$

- $>45$

\section{Level of education}

- Bachelor

- Master

- Ph.D.

$\begin{array}{cc}6 & 20 \% \\ 15 & 50 \% \\ 9 & 30 \%\end{array}$

\section{Construction industry experience (in years)}

- $<10$

- $10-20$

$46.7 \%$

11

$36.7 \%$

- >20

5

$16.7 \%$

\section{Activity field}

- Governmental

- Private

- Both

\section{Responsibility}

- Client

- Consultant

5

- Contractor

\section{Specialty field (Position)}

- Architect

- Director

- Engineer - Civil, Electrical and Mechanical

- General Manger - Procurement and Contracts

- Project Manager

- Senior Project Manager

- Technical Director

\begin{tabular}{cc}
9 & $30 \%$ \\
8 & $26.7 \%$ \\
13 & $43.3 \%$ \\
\hline
\end{tabular}

2

$\begin{array}{cc}2 & 6.7 \% \\ 21 & 70 \% \\ 7 & 23.3 \%\end{array}$

8

$26.7 \%$

16

$53.3 \%$

6 $20 \%$

5

$16.7 \%$

$3 \quad 13.3 \%$

$7 \quad 23.3 \%$

$3 \quad 10 \%$

$3 \quad 10 \%$

$4 \quad 13.3 \%$

4

$13.3 \%$

Table II: Identified risks affecting the objectives of RCPs based on the review of the literature

\begin{tabular}{|c|c|c|c|}
\hline No. & $\begin{array}{c}\text { Chapter RBS } \\
\text { level } 1\end{array}$ & $\begin{array}{c}\text { Group RBS } \\
\text { level } 2\end{array}$ & $\begin{array}{c}\text { Risk RBS } \\
\text { level } 3\end{array}$ \\
\hline 1 & \multirow{4}{*}{ External } & \multirow{2}{*}{ Social } & Dissatisfaction \\
\hline 2 & & & Sabotage \\
\hline 3 & & \multirow{2}{*}{ Economical } & Exchange rate fluctuation \\
\hline 4 & & & Inflation \\
\hline
\end{tabular}




\begin{tabular}{|c|c|c|c|}
\hline 5 & & & Government economic policies \\
\hline 6 & & \multirow{3}{*}{ Political } & Government policies \\
\hline 7 & & & Foreign threats \\
\hline 8 & & & Political events \\
\hline 9 & & \multirow{4}{*}{ Legal } & Changes in law \\
\hline 10 & & & Standards and requirements \\
\hline 11 & & & Regional standards \\
\hline 12 & & & Changing point view of government organization \\
\hline 13 & & \multirow{4}{*}{ Natural } & Earthquake \\
\hline 14 & & & Storm \\
\hline 15 & & & Flood \\
\hline 16 & & & Fire \\
\hline 17 & & \multirow{2}{*}{ Technical } & Lack of documentation on the changes in project \\
\hline 18 & & & Lack of acceptance changes control \\
\hline 19 & \multirow{14}{*}{ Internal } & \multirow{5}{*}{ Work force } & Availability of skilled worker \\
\hline 20 & & & Salary amount \\
\hline 21 & & & Work standards and behavior \\
\hline 22 & & & Skill efficiency \\
\hline 23 & & & Unrealistic primary estimation \\
\hline 24 & & \multirow{3}{*}{ Investment } & Lack of finance \\
\hline 25 & & & Bankruptcy \\
\hline 26 & & & Mismatch between demand and available resources \\
\hline 27 & & \multirow{4}{*}{ Management } & Client records and experience \\
\hline 28 & & & Delay in land hand over \\
\hline 29 & & & Poor coordination and management \\
\hline 30 & & & Lack of using management methods \\
\hline 31 & & \multirow{2}{*}{ Safety } & Building site safety \\
\hline 32 & & & Hygiene \\
\hline
\end{tabular}




\begin{tabular}{|c|c|c|}
\hline 33 & & Environment \\
\hline 34 & \multirow{6}{*}{ Design } & Technical ability and authority of counselor \\
\hline 35 & & Inadequate geotechnical studies \\
\hline 36 & & Failure to identify underground factors \\
\hline 37 & & Workshop supervision \\
\hline 38 & & Incomplete plans \\
\hline 39 & & Poor technical characteristics \\
\hline 40 & \multirow{5}{*}{ Contract } & Contractor contract (listed, fixed) \\
\hline 41 & & Contractor policies to enter biddings \\
\hline 42 & & Incomplete duties, agreements, and contracts \\
\hline 43 & & Contractor claims \\
\hline 44 & & Legal claims \\
\hline 45 & \multirow{3}{*}{ Market } & Increasing work competition \\
\hline 46 & & Change in demand purchases \\
\hline 47 & & Facilitating sales and commercial marketing \\
\hline 48 & \multirow{6}{*}{ Environmental } & Adjacent building condition \\
\hline 49 & & Smoke, pollution, noise \\
\hline 50 & & Building workshop security \\
\hline 51 & & Historical condition \\
\hline 52 & & Historical buildings' privacy space \\
\hline 53 & & Geographic and climatic condition \\
\hline
\end{tabular}

Table III: Expert numbers and minimum size in content validity

\begin{tabular}{ccccccccc}
\hline Expert number & $\mathbf{5}$ & $\mathbf{6}$ & $\mathbf{7}$ & $\mathbf{8}$ & $\mathbf{9}$ & $\mathbf{1 0}$ & $\mathbf{1 1}$ & $\mathbf{1 2}$ \\
\hline Minimum size & 0.99 & 0.99 & 0.99 & 0.85 & 0.78 & 0.62 & 0.59 & 0.56 \\
\hline Expert number & $\mathbf{1 3}$ & $\mathbf{1 4}$ & $\mathbf{1 5}$ & $\mathbf{2 0}$ & $\mathbf{2 5}$ & $\mathbf{3 0}$ & $\mathbf{3 5}$ & $\mathbf{4 0}$ \\
\hline
\end{tabular}




\section{Minimum size}

Table IV: Evaluating content validity of each risk factor of the questionnaire by Lavshh formula

\begin{tabular}{|c|c|c|c|c|c|c|}
\hline No. & Group & Factors & $\begin{array}{l}\text { Approval } \\
\text { opinion }\end{array}$ & $\begin{array}{l}\text { Opposite } \\
\text { opinion }\end{array}$ & $\begin{array}{c}\text { Without } \\
\text { any } \\
\text { opinion }\end{array}$ & $\begin{array}{c}\text { Conten } \\
\text { validity } \\
\text { rate }\end{array}$ \\
\hline 1 & \multirow{4}{*}{ Social } & $\begin{array}{l}\text { General dissatisfaction with the } \\
\text { project's location }\end{array}$ & 30 & 0 & 0 & 1.14 \\
\hline 2 & & Sabotage & 27 & 2 & 1 & 0.93 \\
\hline 3 & & $\begin{array}{l}\text { Cultural difference between } \\
\text { people }\end{array}$ & 27 & 1 & 2 & 0.93 \\
\hline 4 & & Regional and ethnic limitation & 25 & 4 & 1 & 0.79 \\
\hline 5 & \multirow{5}{*}{ Economic } & Exchange rate fluctuation & 30 & 0 & 0 & 1.14 \\
\hline 6 & & Inflation fluctuation & 28 & 2 & 0 & 1 \\
\hline 7 & & Bank interest fluctuation & 28 & 1 & 1 & 1 \\
\hline 8 & & $\begin{array}{l}\text { Change in duties of imported } \\
\text { equipment }\end{array}$ & 27 & 2 & 1 & 0.93 \\
\hline 9 & & $\begin{array}{l}\text { Law changes and economic } \\
\text { policies of materials }\end{array}$ & 27 & 2 & 1 & 0.93 \\
\hline 10 & \multirow{4}{*}{ Political } & $\begin{array}{l}\text { Government internal policies } \\
\text { contradiction }\end{array}$ & 29 & 1 & 0 & 1.07 \\
\hline 11 & & Foreign threats & 22 & 4 & 4 & 0.57 \\
\hline 12 & & $\begin{array}{l}\text { Inappropriate work relation of } \\
\text { government organizations }\end{array}$ & 25 & 3 & 2 & 0.79 \\
\hline 13 & & Government instability & 26 & 2 & 2 & 0.86 \\
\hline 14 & \multirow{3}{*}{ Legal } & Changes in law & 26 & 1 & 3 & 0.86 \\
\hline 15 & & $\begin{array}{l}\text { Changes in binding legal } \\
\text { obligations in contracts }\end{array}$ & 24 & 5 & 1 & 0.71 \\
\hline 16 & & $\begin{array}{l}\text { Regional standard changes } \\
\text { (firefighting-master plans, etc.) }\end{array}$ & 22 & 5 & 3 & 0.57 \\
\hline 17 & \multirow{4}{*}{ Accidents } & $\begin{array}{l}\text { Natural disasters (flood - } \\
\text { earthquake, etc.) }\end{array}$ & 25 & 2 & 3 & 0.79 \\
\hline 18 & & $\begin{array}{l}\text { Sewage and water network } \\
\text { unexpected accidents }\end{array}$ & 25 & 1 & 4 & 0.79 \\
\hline 19 & & Annual change in weather & 26 & 2 & 2 & 0.86 \\
\hline 20 & & $\begin{array}{l}\text { Electrical distribution network } \\
\text { unexpected accident }\end{array}$ & 24 & 3 & 3 & 0.71 \\
\hline 21 & \multirow{3}{*}{ Market } & $\begin{array}{l}\text { Mismatching spaces with } \\
\text { customer needs }\end{array}$ & 30 & 0 & 0 & 1.14 \\
\hline 22 & & Public lack of interest & 28 & 1 & 1 & 1 \\
\hline 23 & & $\begin{array}{l}\text { Increased work competition } \\
\text { around project area }\end{array}$ & 29 & 1 & 0 & 1.07 \\
\hline
\end{tabular}




\begin{tabular}{|c|c|c|c|c|c|c|}
\hline 24 & & $\begin{array}{l}\text { Changes in demand for the } \\
\text { purchase of spaces with different } \\
\text { uses }\end{array}$ & 29 & 1 & 0 & 1.07 \\
\hline 25 & & $\begin{array}{l}\text { Facilitate sales and marketing } \\
\text { conditions for specific user spaces }\end{array}$ & 30 & 0 & 0 & 1.14 \\
\hline 26 & \multirow{4}{*}{ Work force } & Access to skilled worker & 29 & 1 & 0 & 1.07 \\
\hline 27 & & Salary & 27 & 3 & 0 & 0.93 \\
\hline 28 & & $\begin{array}{l}\text { Behavior, standards, work } \\
\text { commitment }\end{array}$ & 27 & 2 & 1 & 0.93 \\
\hline 29 & & $\begin{array}{l}\text { Mismatch job referrals to } \\
\text { personnel with related specialized } \\
\text { skills }\end{array}$ & 29 & 1 & 0 & 1.07 \\
\hline 30 & \multirow{5}{*}{ Investment } & Unrealistic primary estimation & 27 & 3 & 0 & 0.93 \\
\hline 31 & & Inappropriate finance & 30 & 0 & 0 & 1.14 \\
\hline 32 & & Lack of on time finance & 25 & 6 & 2 & 0.79 \\
\hline 33 & & Bankruptcy & 27 & 3 & 0 & 0.93 \\
\hline 34 & & $\begin{array}{l}\text { Mismatch between demand and } \\
\text { available resources }\end{array}$ & 29 & 1 & 0 & 1.07 \\
\hline 35 & \multirow{6}{*}{ Management } & $\begin{array}{l}\text { Previous employer-related } \\
\text { experience and background }\end{array}$ & 30 & 0 & 0 & 1.14 \\
\hline 36 & & $\begin{array}{l}\text { Site unavailability and delay in } \\
\text { delivery of land to the presenter }\end{array}$ & 30 & 0 & 0 & 1.14 \\
\hline 37 & & $\begin{array}{l}\text { Unauthorized allocation of funds } \\
\text { at various stages }\end{array}$ & 29 & 1 & 0 & 1.07 \\
\hline 38 & & Lack of realistic goals & 29 & 1 & 0 & 1.07 \\
\hline 39 & & $\begin{array}{l}\text { Poor coordination and } \\
\text { management }\end{array}$ & 29 & 1 & 0 & 1.07 \\
\hline 40 & & $\begin{array}{l}\text { Lack of using appropriate } \\
\text { methods in workshop } \\
\text { management }\end{array}$ & 27 & 2 & 1 & 0.93 \\
\hline 41 & \multirow{3}{*}{$\begin{array}{c}\text { Project } \\
\text { communication }\end{array}$} & $\begin{array}{l}\text { Lack of proper organizational } \\
\text { coordination }\end{array}$ & 27 & 3 & 0 & 0.93 \\
\hline 42 & & $\begin{array}{l}\text { Project staff crisis in different } \\
\text { units }\end{array}$ & 30 & 0 & 0 & 1.14 \\
\hline 43 & & $\begin{array}{l}\text { Assign responsibility of units to a } \\
\text { third party }\end{array}$ & 30 & 0 & 0 & 1.14 \\
\hline 44 & \multirow{7}{*}{ Design } & Lack of qualified consultant & 27 & 1 & 2 & 0.93 \\
\hline 45 & & Incomplete plan & 30 & 0 & 0 & 1.14 \\
\hline 46 & & Poor technical specifications & 30 & 0 & 0 & 1.14 \\
\hline 47 & & $\begin{array}{l}\text { Mismatch of layout with site } \\
\text { location }\end{array}$ & 29 & 0 & 1 & 1.07 \\
\hline 48 & & $\begin{array}{l}\text { Inaccuracies in realistic } \\
\text { calculations and estimates }\end{array}$ & 27 & 3 & 0 & 0.93 \\
\hline 49 & & $\begin{array}{l}\text { Non-compliance with design } \\
\text { codes }\end{array}$ & 30 & 0 & 0 & 1.14 \\
\hline 50 & & $\begin{array}{l}\text { Lack of maintenance period in } \\
\text { designing process }\end{array}$ & 30 & 0 & 0 & 1.14 \\
\hline 51 & \multirow{5}{*}{ Construction } & $\begin{array}{l}\text { Lack of a specific contract with } \\
\text { contractors }\end{array}$ & 30 & 0 & 0 & 1.14 \\
\hline 52 & & Contractor's claim & 30 & 0 & 0 & 1.14 \\
\hline 53 & & $\begin{array}{l}\text { Lack of coordination between the } \\
\text { design process and manufacturing } \\
\text { technology }\end{array}$ & 30 & 0 & 0 & 1.14 \\
\hline 54 & & Claims & 27 & 3 & 0 & 0.93 \\
\hline 55 & & $\begin{array}{l}\text { Lack of timely completion of } \\
\text { geotechnical studies and } \\
\text { identification of underground } \\
\text { factors }\end{array}$ & 29 & 1 & 0 & 1.07 \\
\hline
\end{tabular}




\begin{tabular}{|c|c|c|c|c|c|c|}
\hline 56 & & Delays in construction & 29 & 1 & 0 & 1.07 \\
\hline 57 & & $\begin{array}{l}\text { Poor quality of workshop } \\
\text { supervision }\end{array}$ & 28 & 2 & 0 & 1 \\
\hline 58 & & $\begin{array}{l}\text { Incomplete description of tasks in } \\
\text { contracts }\end{array}$ & 26 & 1 & 3 & 0.86 \\
\hline 59 & & $\begin{array}{l}\text { Failure to complete work items in } \\
\text { anticipated times }\end{array}$ & 28 & 0 & 2 & 1 \\
\hline 60 & Timetable & $\begin{array}{l}\text { Mismatching physical progress } \\
\text { with the comprehensive project } \\
\text { schedule }\end{array}$ & 30 & 0 & 0 & 1.14 \\
\hline 61 & & $\begin{array}{l}\text { Delay in project duration due to } \\
\text { lack of parallel work }\end{array}$ & 28 & 1 & 1 & 1 \\
\hline 62 & & Delay in completion of the project & 27 & 3 & 1 & 0.93 \\
\hline 63 & \multirow{10}{*}{ Exploitation } & Increase in exploitation costs & 28 & 2 & 0 & 1 \\
\hline 64 & & Increase in maintenance cost & 27 & 1 & 2 & 0.93 \\
\hline 65 & & $\begin{array}{l}\text { Inappropriate pricing of saleable } \\
\text { spaces }\end{array}$ & 28 & 2 & 0 & 1 \\
\hline 66 & & $\begin{array}{l}\text { Lack of proper internal zoning of } \\
\text { spaces in the business center }\end{array}$ & 30 & 0 & 0 & 1.14 \\
\hline 67 & & $\begin{array}{l}\text { Luxury businesses in the vicinity } \\
\text { of ordinary businesses }\end{array}$ & 29 & 1 & 0 & 1.07 \\
\hline 68 & & Poor wide advertising & 29 & 1 & 0 & 1.07 \\
\hline 69 & & $\begin{array}{l}\text { Ignorance of security and safety } \\
\text { protocol }\end{array}$ & 28 & 2 & 0 & 1 \\
\hline 70 & & $\begin{array}{l}\text { Lack of crisis management in } \\
\text { CRCBPs }\end{array}$ & 29 & 1 & 0 & 1.07 \\
\hline 71 & & $\begin{array}{l}\text { Lack of specific instructions in } \\
\text { case of unexpected events }\end{array}$ & 29 & 1 & 0 & 1.07 \\
\hline 72 & & $\begin{array}{l}\text { Lack of maintenance team } \\
\text { stationed in the CRCBPs }\end{array}$ & 28 & 2 & 0 & 1 \\
\hline 73 & \multirow{5}{*}{ Environmental } & Adjacent building condition & 28 & 2 & 0 & 1 \\
\hline 74 & & Historical conditions & 29 & 1 & 0 & 1.07 \\
\hline 75 & & Traffic permits & 28 & 2 & 0 & 1 \\
\hline 76 & & Privacy of monuments in the area & 28 & 1 & 1 & 1 \\
\hline 77 & & $\begin{array}{l}\text { Workshop security in terms of } \\
\text { side access }\end{array}$ & 29 & 1 & 0 & 1.07 \\
\hline 78 & \multirow{3}{*}{ Logistics } & Timely supply of materials & 30 & 0 & 0 & 1.14 \\
\hline 79 & & $\begin{array}{l}\text { Supply of materials according to } \\
\text { technical specifications }\end{array}$ & 27 & 3 & 0 & 0.93 \\
\hline 80 & & $\begin{array}{l}\text { Predicting spare parts for } \\
\text { emergency repairs and } \\
\text { installations }\end{array}$ & 28 & 1 & 1 & 1 \\
\hline
\end{tabular}




\begin{tabular}{clcccc}
\hline 81 & $\begin{array}{l}\text { Lack of instructions for ordering } \\
\text { goods and services }\end{array}$ & 26 & 4 & 0 & 0.86 \\
\cline { 3 - 6 } 82 & $\begin{array}{l}\text { Lack of instructions for ordering } \\
\text { items in project warehouse }\end{array}$ & 23 & 6 & 1 & 0.64 \\
\hline
\end{tabular}

Table V: Expert opinions on Probability and Impact of risks

\section{Expert opinions}

\begin{tabular}{llccc}
\hline \multirow{2}{*}{ Risk } & $\begin{array}{l}\text { Probability of } \\
\text { occurrence }(\mathrm{P})\end{array}$ & $\begin{array}{c}\text { Impact on project } \\
\text { time }\left(\mathrm{I}_{\mathrm{t}}\right)\end{array}$ & $\begin{array}{c}\text { Impact on project } \\
\operatorname{cost}\left(\mathrm{I}_{\mathrm{C}}\right)\end{array}$ & $\begin{array}{c}\text { Impact on project } \\
\text { quality }\left(\mathrm{I}_{\mathrm{q}}\right)\end{array}$ \\
\hline
\end{tabular}

Table VI: Calculation of PRI based on the Probability and Impact of risks

\begin{tabular}{ccccc}
\hline & Probability and Impact & \\
\hline \multirow{2}{*}{ Risk } & $\begin{array}{c}\text { Probability }+ \text { impact on } \\
\text { project time }\left(\mathrm{PI}_{\mathrm{t}}\right)\end{array}$ & $\begin{array}{c}\text { Probability }+ \text { impact on } \\
\text { project cost }\left(\mathrm{PI}_{\mathrm{c}}\right)\end{array}$ & $\begin{array}{c}\text { Probability }+ \text { impact on } \\
\text { project quality }(\mathrm{PIq})\end{array}$ & $\begin{array}{c}\text { primary risk } \\
\text { index }(\mathrm{PRI})\end{array}$ \\
\hline
\end{tabular}

Table VII: $P R I$ and $A P R I$ results of qualitative risk evaluation

\begin{tabular}{|c|c|c|c|c|c|c|c|}
\hline No. & Chapter & Group & Risks & $\sum P R I$ & $\begin{array}{l}\text { Sample } \\
\text { size }\end{array}$ & APRI & $\begin{array}{l}\text { Risk } \\
\text { ranking }\end{array}$ \\
\hline 1 & \multirow{10}{*}{ Internal } & \multirow{4}{*}{ Social } & $\begin{array}{l}\text { General dissatisfaction with the project's } \\
\text { location }\end{array}$ & 6.3 & 28 & 0.225 & 67 \\
\hline 2 & & & Sabotage & 8.26 & 28 & 0.295 & 58 \\
\hline 3 & & & Cultural difference between people & 3.48 & 28 & 0.124 & 81 \\
\hline 4 & & & Regional and ethnic limitation & 4.18 & 28 & 0.149 & 79 \\
\hline 5 & & \multirow{5}{*}{ Economic } & Exchange rate fluctuation & 46.36 & 28 & 1.655 & 1 \\
\hline 6 & & & Inflation fluctuation & 25.23 & 28 & 1.615 & 2 \\
\hline 7 & & & Bank interest fluctuation & 14.44 & 28 & 0.872 & 6 \\
\hline 8 & & & Change in duties of imported equipment & 18.92 & 28 & 0.675 & 18 \\
\hline 9 & & & $\begin{array}{l}\text { Law changes and economic policies of } \\
\text { materials }\end{array}$ & 17.76 & 28 & 0.634 & 21 \\
\hline 10 & & Political & $\begin{array}{l}\text { Government internal policies } \\
\text { contradiction }\end{array}$ & 13.67 & 28 & 0.488 & 35 \\
\hline
\end{tabular}




\begin{tabular}{|c|c|c|c|c|c|c|c|}
\hline 11 & & & Foreign threats & 24.49 & 28 & 0.874 & 5 \\
\hline 12 & & & $\begin{array}{l}\text { Inappropriate work relation of } \\
\text { government organizations }\end{array}$ & 11.68 & 28 & 0.417 & 46 \\
\hline 13 & & & Government instability & 10.20 & 28 & 0.346 & 50 \\
\hline 14 & & & Changes in law & 12.38 & 28 & 0.442 & 43 \\
\hline 15 & & Legal & $\begin{array}{l}\text { Changes in binding legal obligations in } \\
\text { contracts }\end{array}$ & 8.28 & 28 & 0.295 & 57 \\
\hline 16 & & & $\begin{array}{l}\text { Regional standard changes (firefighting- } \\
\text { master plans, etc.) }\end{array}$ & 19.58 & 28 & 0.699 & 14 \\
\hline 17 & & & $\begin{array}{l}\text { Natural disasters (flood - earthquake, } \\
\text { etc.) }\end{array}$ & 13.50 & 28 & 0.482 & 36 \\
\hline 18 & & Accidents & $\begin{array}{l}\text { Sewage and water network unexpected } \\
\text { accidents }\end{array}$ & 2.28 & 28 & 0.0814 & 82 \\
\hline 19 & & & Annual change in weather & 7.860 & 28 & 0.280 & 59 \\
\hline 20 & & & $\begin{array}{l}\text { Electrical distribution network } \\
\text { unexpected accident }\end{array}$ & 3.80 & 28 & 0.135 & 80 \\
\hline 21 & & & $\begin{array}{l}\text { Mismatching spaces with customer } \\
\text { needs }\end{array}$ & 6.74 & 28 & 0.240 & 65 \\
\hline 22 & & & Public lack of interest & 6.57 & 28 & 0.234 & 66 \\
\hline 23 & & Market & $\begin{array}{l}\text { Increased work competition around } \\
\text { project area }\end{array}$ & 7.42 & 28 & 0.265 & 62 \\
\hline 24 & & & $\begin{array}{l}\text { Changes in demand for the purchase of } \\
\text { spaces with different uses }\end{array}$ & 4.52 & 28 & 0.161 & 77 \\
\hline 25 & & & $\begin{array}{l}\text { Facilitate sales and marketing conditions } \\
\text { for specific user spaces }\end{array}$ & 4.56 & 28 & 0.162 & 76 \\
\hline 26 & & & Access to skilled worker & 25.02 & 28 & 0.893 & 3 \\
\hline 27 & & Work force & Salary & 19.54 & 28 & 0.697 & 15 \\
\hline 28 & & & Behavior, standards, work commitment & 14.01 & 28 & 0.500 & 33 \\
\hline 29 & & & $\begin{array}{l}\text { Mismatch job referrals to personnel with } \\
\text { related specialized skills }\end{array}$ & 20.72 & 28 & 0.74 & 11 \\
\hline 30 & & Investment & Unrealistic primary estimation & 22.66 & 28 & 0.809 & 9 \\
\hline 31 & & & Inappropriate finance & 18.21 & 28 & 0.647 & 20 \\
\hline 32 & & & Lack of on time finance & 18.72 & 28 & 0.668 & 19 \\
\hline 33 & & & Bankruptcy & 17.360 & 28 & 0.62 & 22 \\
\hline 34 & & & $\begin{array}{l}\text { Mismatch between demand and available } \\
\text { resources }\end{array}$ & 19.440 & 28 & 0.694 & 16 \\
\hline 35 & \multirow{6}{*}{ External } & \multirow{6}{*}{ Management } & $\begin{array}{l}\text { Previous employer-related experience } \\
\text { and background }\end{array}$ & 20.72 & 28 & 0.694 & 16 \\
\hline 36 & & & $\begin{array}{l}\text { Site unavailability and delay in delivery } \\
\text { of land to the presenter }\end{array}$ & 13.72 & 28 & 0.49 & 34 \\
\hline 37 & & & $\begin{array}{l}\text { Unauthorized allocation of funds at } \\
\text { various stages }\end{array}$ & 11.04 & 28 & 0.39 & 47 \\
\hline 38 & & & Lack of realistic goals & 7.47 & 28 & 0.266 & 61 \\
\hline 39 & & & Poor coordination and management & 14.10 & 28 & 0.503 & 32 \\
\hline 40 & & & $\begin{array}{l}\text { Lack of using appropriate methods in } \\
\text { workshop management }\end{array}$ & 19.08 & 28 & 0.681 & 17 \\
\hline
\end{tabular}




\begin{tabular}{|c|c|c|c|c|c|c|}
\hline 41 & Proiect & $\begin{array}{l}\text { Lack of proper organizational } \\
\text { coordination }\end{array}$ & 12.62 & 28 & 0.450 & 40 \\
\hline 42 & communication & Project staff crisis in different units & 10.22 & 28 & 0.365 & 49 \\
\hline 43 & & $\begin{array}{l}\text { Assign responsibility of units to a third } \\
\text { party }\end{array}$ & 8.32 & 28 & 0.297 & 55 \\
\hline 44 & \multirow{7}{*}{ Design } & Lack of qualified consultant & 23.44 & 28 & 0.837 & 7 \\
\hline 45 & & Incomplete plan & 17.22 & 28 & 0.611 & 23 \\
\hline 46 & & Poor technical specifications & 17.04 & 28 & 0.608 & 24 \\
\hline 47 & & Mismatch of layout with site location & 12.62 & 28 & 0.455 & 39 \\
\hline 48 & & $\begin{array}{l}\text { Inaccuracies in realistic calculations and } \\
\text { estimates }\end{array}$ & 14.90 & 28 & 0.532 & 30 \\
\hline 49 & & Non-compliance with design codes & 7.84 & 28 & 0.28 & 60 \\
\hline 50 & & $\begin{array}{l}\text { Lack of maintenance period in designing } \\
\text { process }\end{array}$ & 8.64 & 28 & 0.308 & 53 \\
\hline 51 & \multirow{8}{*}{ Construction } & $\begin{array}{l}\text { Lack of a specific contract with } \\
\text { contractors }\end{array}$ & 15.14 & 28 & 0.540 & 29 \\
\hline 52 & & Contractor's claim & 24.98 & 28 & 0.892 & 4 \\
\hline 53 & & $\begin{array}{l}\text { Lack of coordination between the design } \\
\text { process and manufacturing technology }\end{array}$ & 13.44 & 28 & 0.48 & 37 \\
\hline 54 & & Claims & 12.50 & 28 & 0.446 & 42 \\
\hline 55 & & $\begin{array}{l}\text { Lack of timely completion of } \\
\text { geotechnical studies and identification } \\
\text { underground factors }\end{array}$ & 11.02 & 28 & 0.393 & 48 \\
\hline 56 & & Delays in construction & 20.26 & 28 & 0.723 & 13 \\
\hline 57 & & Poor quality of workshop supervision & 16.36 & 28 & 0.58 & 26 \\
\hline 58 & & $\begin{array}{l}\text { Incomplete description of tasks in } \\
\text { contracts }\end{array}$ & 9.10 & 28 & 0.325 & 52 \\
\hline 59 & \multirow{4}{*}{ Timetable } & $\begin{array}{l}\text { Failure to complete work items in } \\
\text { anticipated times }\end{array}$ & 16.90 & 28 & 0.603 & 25 \\
\hline 60 & & $\begin{array}{l}\text { Mismatching physical progress with the } \\
\text { comprehensive project schedule }\end{array}$ & 13.14 & 28 & 0.469 & 38 \\
\hline 61 & & $\begin{array}{l}\text { Delay in project duration due to lack of } \\
\text { parallel work }\end{array}$ & 13.54 & 28 & 0.447 & 41 \\
\hline 62 & & Delay in completion of the project & 16.24 & 28 & 0.58 & 27 \\
\hline 63 & \multirow{7}{*}{ Exploitation } & Increase in exploitation costs & 4.58 & 28 & 0.163 & 75 \\
\hline 64 & & Increase in maintenance cost & 5.42 & 28 & 0.193 & 71 \\
\hline 65 & & Inappropriate pricing of saleable spaces & 5.34 & 28 & 0.190 & 72 \\
\hline 66 & & $\begin{array}{l}\text { Lack of proper internal zoning of spaces } \\
\text { in the business center }\end{array}$ & 5.610 & 28 & 0.200 & 70 \\
\hline 67 & & $\begin{array}{l}\text { Luxury businesses in the vicinity of } \\
\text { ordinary businesses }\end{array}$ & 4.58 & 28 & 0.163 & 75 \\
\hline 68 & & Poor wide advertising & 4.24 & 28 & 0.151 & 78 \\
\hline 69 & & Ignorance of security and safety protocol & 5.24 & 28 & 0.187 & 73 \\
\hline
\end{tabular}




\begin{tabular}{|c|c|c|c|c|c|c|}
\hline 70 & & Lack of crisis management in CRCBPs & 5.98 & 28 & 0.213 & 68 \\
\hline 71 & & $\begin{array}{l}\text { Lack of specific instructions in case of } \\
\text { unexpected events }\end{array}$ & 7.0 & 28 & 0.253 & 63 \\
\hline 72 & & $\begin{array}{l}\text { Lack of maintenance team stationed in } \\
\text { the CRCBs }\end{array}$ & 7.02 & 28 & 0.250 & 64 \\
\hline 73 & \multirow{5}{*}{ Environmental } & Adjacent building condition & 21.84 & 28 & 0.78 & 10 \\
\hline 74 & & Historical conditions & 8.52 & 28 & 0.304 & 54 \\
\hline 75 & & Traffic permits & 22.82 & 28 & 0.815 & 8 \\
\hline 76 & & Privacy of monuments in the area & 5.80 & 28 & 0.207 & 69 \\
\hline 77 & & $\begin{array}{l}\text { Workshop security in terms of side } \\
\text { access }\end{array}$ & 12.80 & 28 & 0.431 & 45 \\
\hline 78 & \multirow{5}{*}{ Logistics } & Timely supply of materials & 15.36 & 28 & 0.548 & 28 \\
\hline 79 & & $\begin{array}{l}\text { Supply of materials according to } \\
\text { technical specifications }\end{array}$ & 12.34 & 28 & 0.440 & 44 \\
\hline 80 & & $\begin{array}{l}\text { Predicting spare parts for emergency } \\
\text { repairs and installations }\end{array}$ & 8.32 & 28 & 0.297 & 56 \\
\hline 81 & & $\begin{array}{l}\text { Lack of instructions for ordering goods } \\
\text { and services }\end{array}$ & 9.47 & 28 & 0.338 & 51 \\
\hline 82 & & $\begin{array}{l}\text { Lack of instructions for ordering items in } \\
\text { project warehouse }\end{array}$ & 14.20 & 28 & 0.507 & 31 \\
\hline
\end{tabular}

